\title{
On elevation models as input for mass-balance calculations of the Greenland ice sheet
}

\author{
R. S. W. VAN DE WAL \\ Institute for Marine and Atmospheric Research Utrecht, Utrecht University, 3584 CC Utrecht, The Netherlands \\ S. EKHOLM \\ Kort -og Matrikelstyrelsen, Rentemestervej 8, DK-2400 Kobenhavn, Denmark
}

\begin{abstract}
In this paper the elevation model for the Greenland ice sheet based upon radio-echo-sounding flights of the Technical University of Denmark (TUD (Letréguilly and others, 1991) are compared with the satellite-altimetry model (Tscherning and others, 1993) improved with airborne-laser and radar altimetry (IA model). Although the general hypsometry of both data sets is rather similar, differences seem to be large at individual points along the ice margin. Over the entire ice sheet, the difference between the IA model and the TUD model is $33 \mathrm{~m}$ with a rootmean-square error of $112 \mathrm{~m}$. Differential GPS measurements collected in the icemarginal zone near Sondre Stromfjord show that the IA model is more accurate than the TUD model. The latter data set underestimates the elevation by approximately $150 \mathrm{~m}$ in the ice-marginal zone near Sondre Stromfjord.

Calculation of the ablation with an energy-balance model and with a degree-day model points to a $20 \%$ decrease in the ablation if the IA model is used. Not only does this show the sensitivity of ablation calculations to the orographic input but it also indicates that the ablation calculated by the models used nowadays is relatively overestimated.
\end{abstract}

\section{INTRODUCTION}

Dynamical modelling of the Greenland ice sheet is seriously hampered by the limited number of measurements that have been made of meteorological and glaciological variables. Often, data have only been collected in restricted coastal areas or during limited time periods, whereas there is a need for long-term measurements in varying climatological areas. To obtain data sets for larger areas, statistical relations are normally derived from the limited measurements available. An example of this approach is the parameterization of the temperature distribution in terms of latitude and elevation by Rech (1991) and Huybrechts and others (1991), which was based upon 18 stations with mean July temperature measurements and six stations with annual mean temperature measurements (Ohmura, 1987). This is more or less the only thing one can do when data sets are so limited and, as long as good statistical correlations are obtained, this approach is acceptable. It should, however, be noted that the use of this procedure introduces an uncertainty in the calculations, if the elevation distribution is poorly known.

For this reason, the best elevation distribution should be used for model studies. Comparing results of different model studies which are not based upon the same input data (for instance elevation) does not provide insight into the various physical processes involved in the model formulations. Most mass-balance modelling work of the Greenland ice sheet done in recent years (Huybrechts and others, 1991; Rech, 1991; Wal and Oerlemans, 1994) has been made possible by the digital elevation model given by Letréguilly and others (1991) as a grid of $20 \mathrm{~km} \times 20 \mathrm{~km}$ resolution. The surface elevations for the ice sheet have been computed from data obtained by radio-echo-sounding flights undertaken by the Electromagnetic Institute (EMI) of the Technical University of Denmark in the late 1970s, further abbreviated as TUD model. The aircraft altitude, and hence the elevations, were derived from a pressure altimeter. To evaluate the accuracy of the data, Letréguilly and others (1991) compared these measurements with terrestrial altimetry measurements at the ice-drilling sites of Dye 3 and Camp Century to examine ice thickness as well as elevation. Letréguilly and others (1991) concluded that the elevation model compared reasonably well with these two point measurements as well as with a published map by Ohmura (1987) and a satellite-altimetry map (south of 
$72^{\circ} \mathrm{N}$ ) by Bindschadler and others (1989). It should be noted that the sites Dye 3 and Camp Century are relatively well covered by the measurements.

The elevation in the ice-marginal zone is very important (a) for mass-balance calculations, because the ablation is concentrated in these areas, and (b) for icedynamical studies, because surface slope near the margin is an important parameter for validating ice-dynamical model performance. Fortunately, new and more accurate elevation measurements are now available. Satellitealtimetry data from GEOSAT (south of $72.1^{\circ} \mathrm{N}$ and ERS 1 (north of $72.1^{\circ} \mathrm{N}$ ), supplemented with airborne altimetry from the so-called Greenland Aerogeophysical Project (GAP) (Brozena, 1991), airborne laser altimetry from the Airborne Ice Mapping project (AIM) (Krabill and others, 1995), and a local terrestrial survey performed on the summit (Ekholm and Keller, 1993), have made it possible to construct a new elevation model for the Greenland ice sheet. The model used in this paper is that of Tscherning and others (1993) improved with airborne laser and radar altimetry (S. Ekholm; a fulcoverage, high-resolution, topographic model of Greenland, computed from a variety of digital elevation data, submitted to Journal of Geophysical Research-Solid Earth). Here, this model is referred to as the integrated-altimetry (IA) model. The model is given as a grid in geographical coordinates with a resolution of $5^{\prime}$ and $10^{\prime}$ in latitudal and longitudal directions, respectively, which corresponds to a grid resolution of approximately $10 \mathrm{~km}$ in latitudinal direction and $3-9 \mathrm{~km}$ in longitudinal direction. A slightly pessimistic estimate of the general accuracy is obtained by omitting the AIM observations from the modelling process and regarding them as ground truth instead. In this manner, an overall accuracy level of $13 \mathrm{~m}$ is found. The AIM survey data are available south of $72^{\circ} \mathrm{N}$, so the true model accuracy is possibly slightly better on the southern ice sheet, within the AIM area of coverage. Satellite-altimetry data are highly unreliable in more steeply sloping areas and the model accuracy near the margin of the ice sheet, with slopes greater than $1^{\circ}$, is probably as limited as $75-100 \mathrm{~m}$.

In this paper, the IA model will be compared with the TUD model. Special attention is given to the icemarginal zone near Sondre Stromfjord, since detailed differential GPS measurements are available for this area. Finally, the discrepancies in ablation of the Greenland ice sheet, as revealed by the two elevation models, will be discussed. The ablation is calculated both with an energybalance model and a degree-day model.

\section{COMPARISON OF THE HYPSOMETRY OF THE GREENLAND ICE SHEET}

Various estimates of the volume $(V)$ and surface area $(A)$ of the Greenland ice sheet have been presented in the literature. Without claiming to be complete, Table 1 presents a compilation of the principal estimates. These estimates are based primarily upon seismic measurements made in the period 1948-53 (Holtzscherer and Bauer, 1955 and improved later on by various regional measurements or other interpolation techniques. The surface elevation for the TUD model is based upon data obtained by radio-echo-sounding flights undertaken by the Electromagnetic Institute (EMI) of the Technical University of Denmark. Satellite-altimetry data from ERS-1, together with GAP airborne altimetry and local terrestrial surveys on the summit, enabled the construction of the IA model. Roughly, we find that the overall estimates of volume, surface and ice thickness vary by approximately $5 \%$ from their mean values. Note that the estimates of volume, area, ice thickness and surface elevation in Table 1 are not entirely independent of each other, because they are based partly on the same data. The data in Table 1, for the IA model, have been interpolated to the $20 \mathrm{~km} \times 20 \mathrm{~km}$ grid used for the TUD model.

If we ignore differences in surface area, we can compare the hypsometry of the estimates presented by Oerlemans and others (1993), the TUD model and the IA model. Oerlemans and others (1993) determined planimetrical elevation intervals from a map given by Weidick (1971). The mean surface elevation of this model is considerably lower than the mean surface elevation of the two other data sets, as can be seen in Table 1. In the distribution used by Oerlemans and others (1993), the surface area of the higher accumulation area is considerably smaller than for the two other data sets. The reason

Table 1. A compilation of various estimates of volume $(V)$, surface area $(A)$, ice thickness $(H)$ and surface elevation $\left(h_{\mathrm{s}}\right)$ of the Greenland ice sheet

\begin{tabular}{|c|c|c|c|c|}
\hline & $\begin{array}{c}V \\
\times 10^{6} \mathrm{~km}^{3}\end{array}$ & $\begin{array}{c}A \\
\times 10^{6} \mathrm{~km}^{2}\end{array}$ & $\begin{array}{c}\text { Mean } H \\
\mathrm{~m}\end{array}$ & $\begin{array}{c}\text { Mean } h_{\mathrm{s}} \\
\text { ma.s.l. }\end{array}$ \\
\hline Holtzscherer and Bauer, 1955 & 2.667 & 1.726 & 1545 & \\
\hline Radok and others, 1982 & 2.988 & 1.670 & 1790 & \\
\hline Weidick, 1985 & & 1.701 & & \\
\hline $\begin{array}{l}\text { TUD model: Letréguilly and } \\
\text { others, } 1991\end{array}$ & 2.825 & 1.671 & 1691 & 2126 \\
\hline $\begin{array}{l}\text { Oerlemans and others, 1993; } \\
\text { Weidick, } 1971\end{array}$ & & & & 1892 \\
\hline IA model $20 \mathrm{~km} \times 20 \mathrm{~km}$ & 2.733 & 1.671 & 1636 & 2159 \\
\hline
\end{tabular}




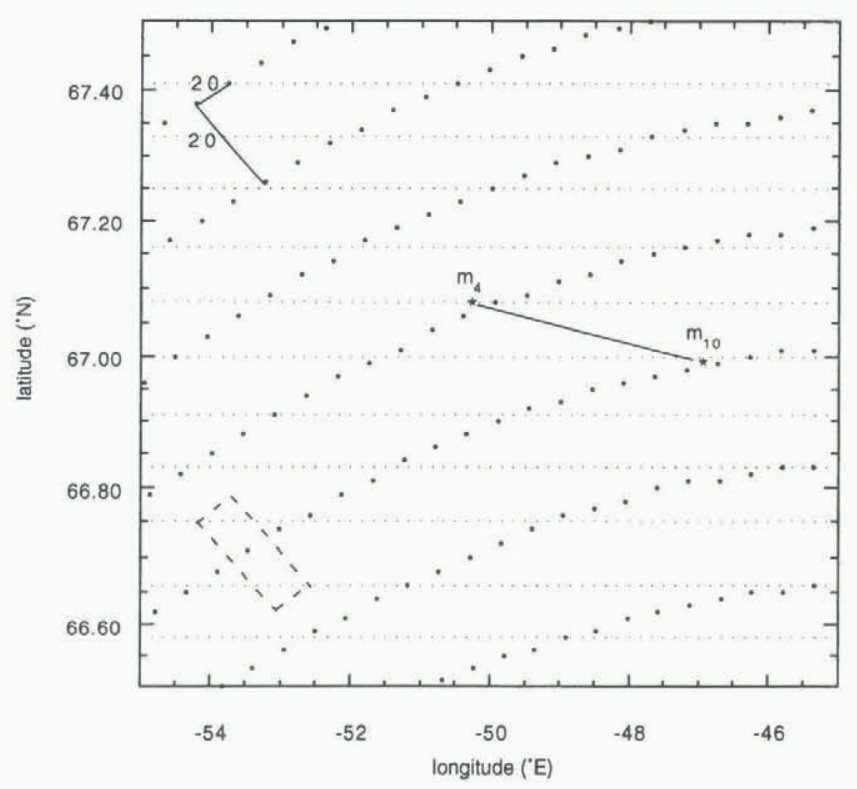

Fig. 1. A close-up of the IA model grid (small dots) and the TUD model grid (large dots). The dots indicate points at which the elevation is prescribed. The dashed rectangle, in the lower left corner is an example of an area used for interpolating the $I A$ model to the $20 \mathrm{~km} \times 20 \mathrm{~km}$ grid. Aboul ten points are used for the interpolation. The line $m_{f}-m_{10}$ indicates the location of the Gimex surfaceelevation measurements. Note that the bars in the upper left comer show the latitudinal exaggeration of the projection in $\mathrm{km}$.

for this difference is unclear. On the other hand, the (ablation) area below $1000 \mathrm{~m}$ a.s.l. is significantly larger in this data set compared to the two other data sets, due to a better resolution of the outlet glaciers. A comparison of the hypsometry of the TUD model and the IA model produces remarkably similar results. To facilitate a comparison, we project the more detailed version of the IA model on the grid points of the TUD model. This projection is achieved by averaging all the elevations of the IA model available within a grid box, in which the sizes of the grid cells are provided by the TUD model (see Fig. 1). Averaging is performed with a scaling of one over the distance in kilometres from the IA coordinate to the TUD coordinate. In this way, approximately ten points from the IA model are used to calculate one elevation at the $20 \mathrm{~km} \times 20 \mathrm{~km}$ grid. The results of this data transformation are presented in Figure 2a. Except around the dip at $2800 \mathrm{~m}$ a.s.l., the hypsometry of the two elevation models is rather similar. One can argue that this might be due to the arbitrary interpolation procedure. We therefore also show in Figure $2 b$ the detailed version of the IA model with a resolution of $5^{\prime}$ and $10^{\prime}$ in latitude and longitude directions, respectively, as well as the interpolated version. Figure $2 \mathrm{~b}$ also shows that the interpolation leads to an underestimation of the area below $500 \mathrm{~m}$ a.s.l., whereas the overall distribution is rather similar. To resolve the outlet glaciers which are typical small-scale features, one needs high resolution as taken into account by Oerlemans and others (1993). Nevertheless, Figure $2 \mathrm{a}$ and $2 \mathrm{~b}$ suggests that the overall geometry is represented in a similar way in both elevation distributions. However, this does not necessarily mean that there are no differences from place to place.
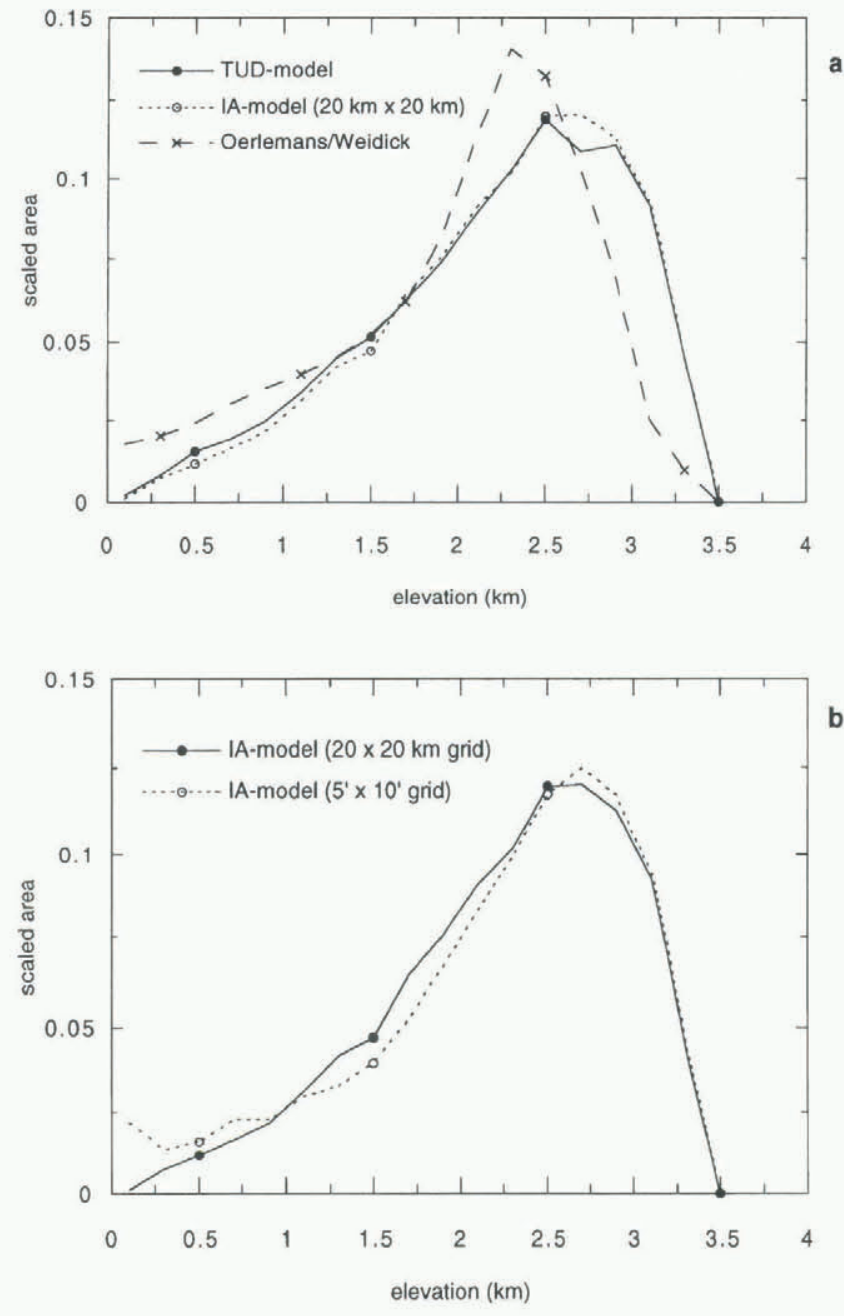

Fig. 2. The hypsometry of the ice sheet for three different data sets, the TUD model and the IA model both on the $20 \mathrm{~km} \times 20 \mathrm{~km}$ grid $(a)$. The hypsometry of the IA model on the $20 \mathrm{~km} \times 20 \mathrm{~km}$ grid and on the $5^{\prime} \times 10^{\prime}$ grid $(b)$.

To study the local differences, we subtracted both surface-elevation distributions from each other at the $20 \mathrm{~km} \times 20 \mathrm{~km}$ grid resolution. Averaging the differences over the ice-sheet area gives on average an elevation difference of $33 \mathrm{~m}$ (see also Table 1). The mean-squarederror of the difference field, as presented in Figure 3, is $112 \mathrm{~m}$. Figure 3 shows these differences over the entire domain. One can observe that in the higher areas of the ice sheet the differences are fairly small, whereas along the margin the discrepancies are considerable. Note that in Figure 3 the plot limits are taken to be $100 \mathrm{~m}$ but at isolated spots differences can be far larger in spite of the similar hypsometry.

In the next section, we compare the two elevation distributions with elevation measurements in an area near the margin, for which the two elevation models revealed large differences.

\section{EXAMINATION OF THE ELEVATION MODELS FOR THE ICE MARGIN NEAR SØNDRE STRØM- FJORD, WEST GREENLAND}

Accurate ground-truth information on the ice-sheet elevation is limited, especially in the ablation zone of 


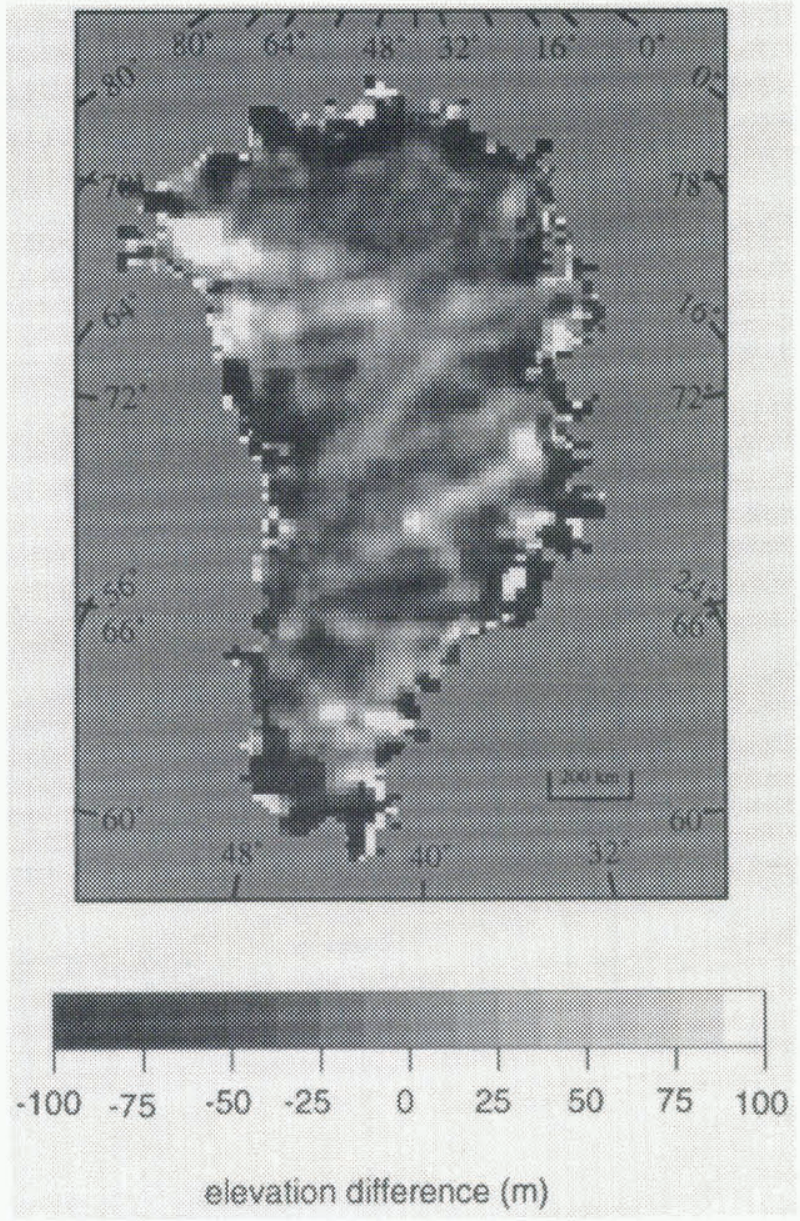

Fig. 3. The difference in elevation revealed by comparing the TUD model and the IA model on the $20 \mathrm{~km} \times 20 \mathrm{~km}$ grid. The plot boundaries are arbitrarily chosen at $100 \mathrm{~m}$; larger discrepancies occur at individual spots. The surrounding grey area indicates the area which is ice-free (tundra and sea).

the ice sheet where surface slopes are relatively large. In the framework of the Gimex micrometeorological experiments, GPS measurements were collected along a transect of about $90 \mathrm{~km}\left(\mathrm{~m}_{4}-\mathrm{m}_{10}\right.$ in Fig. 1) perpendicular to the ice margin near Sondre Stromfjord in the period 1990 94. Two Magellan NAV-100 receivers were used for positioning. The instruments were used in differential mode and the accuracy of the positions is estimated to be $10 \mathrm{~m}$ in horizontal and $20 \mathrm{~m}$ in vertical direction, respectively. Comparing point measurements with a discrete gridded model is always a somewhat awkward exercise, because of the resolution difference. Figure 1 shows the scale difference of the two grids and the transect, $\mathrm{m}_{4}-\mathrm{m}_{10}$, with the measurements. From Figure 1, it can be seen that the transect is covered by about eight grid points in the east-west direction from the TUD model grid and by about 20 from the IA model.

Figure 4a shows the measured elevation together with the bilinearly interpolated elevations of the two models. It can be observed that the differences increase towards the ice margin. The TUD model grid underestimates the elevation west of $-49^{\circ} \mathrm{E}$, typically by $150 \mathrm{~m}$ as can be observed in Figure 4b. In terms of surface slope, this
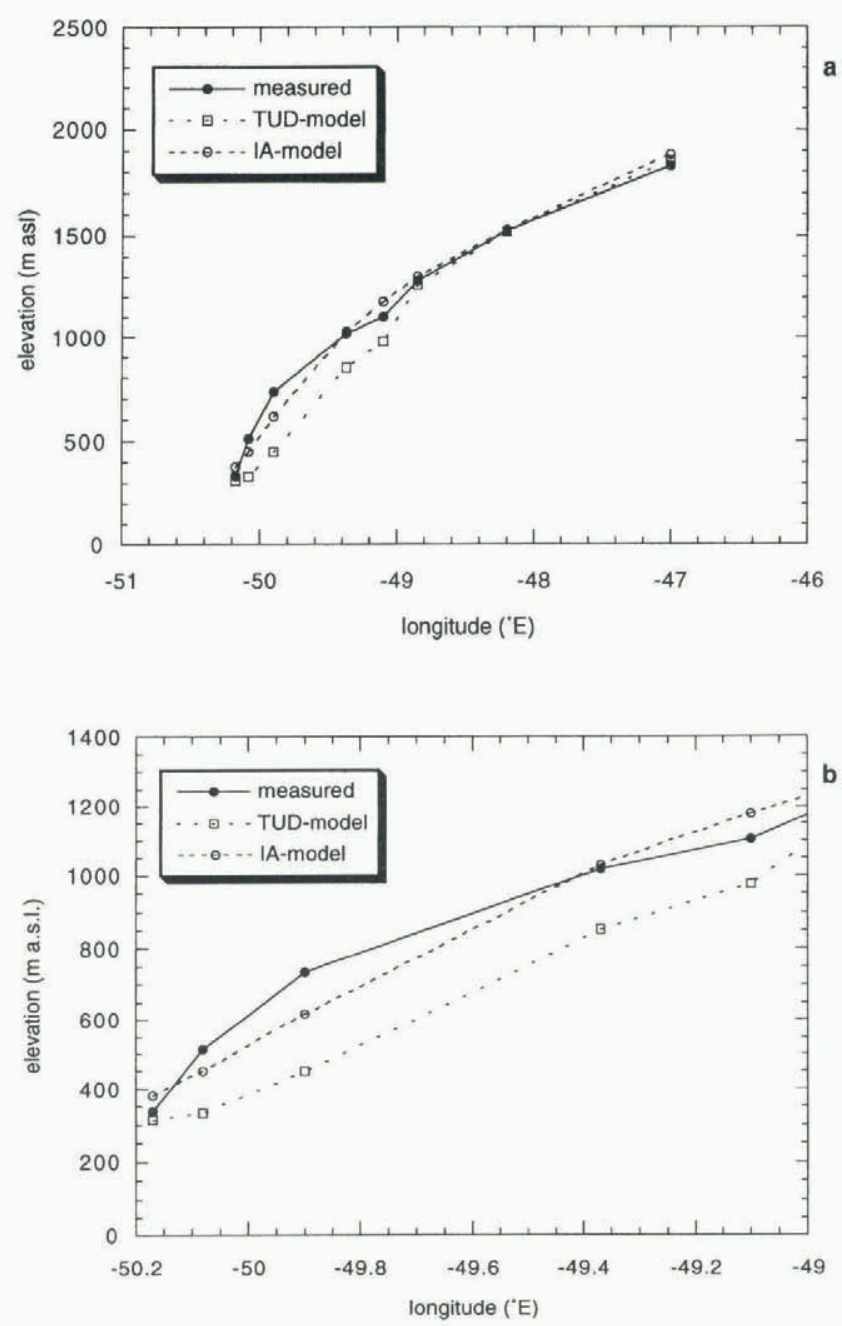

Fig. 4. A comparison of the elevation revealed by the TUD-model and IA-model data with GPS measurements carried out near Sondre Stromfjord in the framework of the Gimex expeditions in the period 1990-95 (a). A close-up of the area below $1300 \mathrm{~m}$ a.s.l. (b).

means that the $20 \mathrm{~km} \times 20 \mathrm{~km}$ grid overestimates the slope by approximately $20 \%$. Higher up on the ice sheet, differences between the two elevation models and the measurements are typically $20 \mathrm{~m}$.

The satellite-altimetry observations are corrected for slope-induced errors according to the so-called "direct" method given in Ekholm and others (1995), resulting in mean errors of $10-35 \mathrm{~m}$ for slopes of $0.3-0.6^{\circ}$. This means that the observed differences between elevation model and GPS measurements (accuracy $20 \mathrm{~m}$ ) are in agreement with the errors in the measurements, in the area above approximately $1300 \mathrm{~m}$ a.s.l., where surface slope is about $0.5^{\circ}$. Lower down on the ice sheet, the mean error of the slope-corrected satellite altimetry increases to approximately $40 \mathrm{~m}$, corresponding to a $1^{\circ}$ slope, the upper part of the allowable surface slope for satellite altimetry (Ekholm and others, 1995). The actual observed surface slope based on the GPS measurements is $2^{\circ}$ at the margin and the standard deviation of the difference between the IA model and the GPS measurement is $72 \mathrm{~m}(N=6)$. In this area, satellite altimetry is unreliable and the estimated accuracy of the elevation model is $75-100 \mathrm{~m}$, which is in line with the observed 


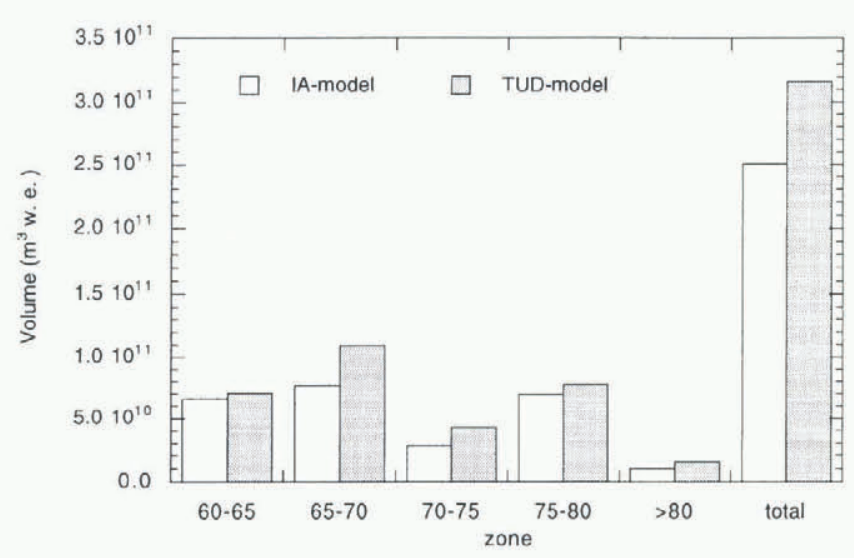

Fig. 5. The ablation on the Greenland ice sheet for different latitudinal zones calculated with an energybalance model (Wal and Oerlemans, 1994). The white bars show the ablation with the IA model as input for the elevation and the grey bars show the ablation with the TUD model as input for the elevation. Both calculations use the $20 \mathrm{~km} \times 20 \mathrm{~km}$ grid.

differences between GPS measurements and the IA model. In spite of the considerable standard deviation the mean difference is only $4 \mathrm{~m}$.

For the TUD model, a systematic difference is observed in Figure $4 \mathrm{a}$ and $\mathrm{b}$ for the lower part of the transect ( $<1300$ ma.s.l.), which is difficult to explain purely from the uncertainty in the measurements. Although this comparison is strictly local, it is likely that errors such as this occur more widely in the $20 \mathrm{~km} \times 20 \mathrm{~km}$ grid. The data of the TUD model are based upon airborne-radar measurements, which rely upon pressure altimetry for the absolute elevation. In areas with rapidly changing elevation, a low frequency of measurements leads to large interpolation errors. This means that near the ice margin the largest errors might be expected for the $20 \mathrm{~km} \times 20 \mathrm{~km}$ grid. Unfortunately, this area is very important, because ice-dynamical models can be tested in these areas in terms of, for instance, surface slope and ice thickness. The ice margin is even more important for ablation models, since ablation is almost entirely restricted to these areas.

\section{DISGREPANGIES IN THE ABLATION OF THE ENTIRE ICE SHEET AS CALCULATED WITH TWO DIFFERENT ELEVATION MODELS AS IN- PUT PARAMETER}

Two alternative approaches are used nowadays to calculate the ablation of the Greenland ice sheet: one is based on the energy balance of the surface, for instance, the model of Wal and Oerlemans (1994), and the other is based on a statistical correlation between temperature and ablation, the so-called degree-day models (Huybrechts and others, 1991; Reeh, 1991). In both approaches, it is assumed that the temperature field can be parameterized as a function of latitude and elevation, on the basis of a compilation of available data by Ohmura (1987). Although the two degree-day models are not identical, these models, as well as the energy-balance model of Wal and Oerlemans (1994), all use a grid with a spacing of $20 \mathrm{~km}$ and the elevation as a main input parameter, as it was digitized for this grid by Letréguilly and others (1991). Altogether, this gives 4219 positions on the ice sheet, representing an area of $1.69 \times 10^{6} \mathrm{~km}^{2}$. A more thorough comparison of energy-balance and degreeday calculation of the ablation has been presented by Wal (1996). Changing the elevation from the TUD model to the IA model and keeping all other model parameters identical (including the resolution) provides insight into the sensitivity of the model to the elevation data. Figure 5 shows the ablation for different latitude zones for the two elevation distributions. Application of the IA model yields a reduction of $20 \%$ in the ablation compared to the application of the TUD model, as calculated by the energy-balance model of Wal and Oerlemans (1994). $50 \%$ of the difference between the two model runs is concentrated in the zone between $65-70^{\circ} \mathrm{N}$ and is primarily on the eastern side of Greenland. The same experiment yields similar results for the degree-day model of Reeh (1991). This large discrepancy between the two elevation models shows that our knowledge of the ablation distribution of the Greenland ice sheet is limited. A change in one of the most basic input parameters, the elevation, can easily yield changes of the order of $20 \%$.

This reduced ablation will, in principal, also reduce the sensitivity of the ice sheet for climate change. Wal (1996) showed that the sensitivity increases for larger perturbations. This implies that a change to a lowerreference ablation distribution results in a smaller sensitivity. For a $1 \mathrm{~K}$ perturbation, the sensitivity of the energy-balance model of Wal and Oerlemans (1994) reduces about $3 \%$, if the input is changed from the TUD model to the IA model, and keeping all other model parameters identical.

\section{CONGLUSIONS}

The paper has focused mainly on a comparison between two elevation models: on the one hand, the TUD model, which has been widely used in glaciological studies, and, on the other hand, the IA model. The comparison has revealed considerable discrepancies along the ice margin on individual grid points and $112 \mathrm{~m} \mathrm{r.m.s}$. over the entire ice sheet, although the overall hypsometry is rather similar. Validating the elevation models in an absolute sense is difficult but a comparison with GPS measurements in the area around Sondre Stromfjord shows that the IA model corresponds much better to the groundtruth observations. The observed standard deviation for the discrepancies between the IA model and the GPS measurements is in line with the conclusions of Ekholm and others (1995) for surface slopes smaller than $1^{\circ}$. For slopes between $1^{\circ}$ and $2^{\circ}$, the standard deviation of the difference between the GPS measurements and the elevation model is found to be $72 \mathrm{~m}$. Because a height difference of this order of magnitude has considerable consequences for the calculation of the ablation, it is necessary that more terrestrial measurements in icemarginal zones are carried out. A second improvement for future work on mass-balance modelling is the increase in resolution to resolve outlet glaciers better (Fig. 2). 
In spite of the rather similar overall geometry of the two elevation models, we observe a $20 \%$ reduction in the ablation when the IA model is used instead of the TUD model, irrespective of the way in which the ablation is calculated. Hence, we conclude that the contribution of the ablation was relatively overestimated previously.

\section{ACKNOWLEDGEMENTS}

We are very grateful to everybody involved in the GIMEX expeditions. S. McNab has patiently corrected the English text. Two reviewers contributed considerably to the quality of the paper. The work is sponsored by The Netherlands Foundation for the Advancement of Pure Research (NWO). Additional support was obtained from the Climate Programme of the European Commission, under contract No. EVUC-0053-NL (GDF).

\section{REFERENCES}

Bindschadler, R. A., H.J. Zwally, J. A. Major and A. C. Brenner. 1989. Surface topography of the Greenland ice sheet from satellite altimetry. Washington, DC, National Aeronautics and Space Administration. (NASA SP-503.

Brozena, J. M. 1991. The Greenland Aerogeophysical Project: airborne gravity, topographic and magnetic mapping of an entire continent. In Colombo, O. L., ed. From Mars to Greenland: charting gravity with space and airborne instruments. New York, Springer-Verlag, 207-214. (International Association of Geodesy Symposium No. 110.)

Ekholm, S. and K. Keller. 1993. Gravity and GPS survey on the summit of the Greenland ice sheet 1991-1992. Copenhagen, Kort- og Matrikelstyrelsen. Geodetic Division. (Technical Report 6.)

Ekholm, S., R. Forsberg and J. M. Brozena. 1995. Accuracy of satellite altimeter elevations over the Greenland ice sheet. \%. Geophys. Res., 100 C2), 2687-2696.

Holtzscherer, J.-J. and A. Bauer. 1955. Contribution à la connaissance de l'inlandsis du Groenland. Première partie: Mesures séismiques par Jean-Jacques Holtzscherer. Deuxiéme partie: Synthèse glaciologique par Albert Bauer. International Association of Scientific Hydrology Publication 39 (General Assembly of Rome 1954 - Snow and Ice), 244296.

Huybrechts, P., A. Letréguilly and N. Reeh. 1991. The Greenland ice sheet and greenhouse warming. Global and Planelary Change, 3 4), 399-412.

Krabill, W. B., R.H. Thomas, C.F. Martin, R. N. Swift and E. B. Frederick. 1995. Accuracy of airborne laser altimetry over the Greenland ice sheet. Int. J. Remote Sensing, 16 (7), 1211-1222.

Letréguilly, A., P. Huybrechts and N. Reeh. 1991. Steady-state characteristics of the Greenland ice sheet under different climates. f. Glaciol., 37 (125), 149-157.

Oerlemans, J., R. S, van de Wal and L. A. Conrads. 1993. A model for the surface balance of ice masses. Part II. Application to the Greenland ice sheet. Z. Gletscherkd. Glazialgeol., 27/28, 1991/1992, 85-96.

Ohmura, A. 1987. New temperature distribution maps for Greenland. Z. Gletscherkd. Glazialgeol., 23(1), 1-45.

Radok, U., R. G. Barry, D. Jenssen, R. A. Keen, G. N. Kiladis and B. McInnes. 1982. Climatic and physical characteristics of the Greenland ice sheet. Part I and II. Boulder, CO, University of Colorado. Cooperative Institute for Research in Environmental Sciences.

Reeh, N. 1991. Parameterization of melt rate and surface temperature on the Greenland ice sheet. Polarforschung, 59(3), 1989, 113-128.

Tscherning, C. C., P. Knudsen, S. Ekholm and O. B. Andersen. 1993. An analysis of the gravity field in the Norwegian Sea and mapping of the ice cap of Greenland using ERS-1 altimeter measurements. In Kaldeich, B., ed. Proceedings of the First ERS-1 Symposium. Space at the Service of our Environment, 4-6 November 1992, Cannes, France, Vol. 1. Paris, European Space Agency, 413-418. (ESA SP-359.)

Wal, R.S. W. van de. 1996. Mass-balance modelling of the Greenland ice sheet: a comparison of an energy-balance model and a degree-day model. Ann. Glaciol., 23 (see paper in this volume).

Wal, R. S. W. van de and J. Oerlemans. 1994. An energy balance model for the Greenland ice sheet. Global and Planetary Change, 9 (1-2), 115-131.

Weidick, A. 1971. Short explanation to the Quaternary map of Greenland. Gronlands Geologiske Undersogelse. Rapport 36.

Weidick, A. 1985. The ice cover of Greenland. Gronlands Geologiske Undersogelse. Gletscher-Hydrologiske Meddelelser 85-4. 